\title{
Hartvig Nissen som grundtvigianer
}

\author{
Jes Fabricius Møller
}

Merethe Roos, Hartvig Nissen. Grundtvigianer, skandinav, skolemann, Cappelen Damm Akademisk 2019, 282 sider.

"Der er Faa eller Ingen i vort Land, der i den Grad har viet sit Liv til et utrætteligt Arbejde i Skolevæsenets Tjeneste som nys afdøde Rektor ved Kristiania Kathedralskole Ole Hartvig Nissen. Lige fra 1843, da han begyndte sin pædagogiske Virksomhed, til sin Død har han i Tale og Skrift belyst de forkjelligste Spørgsmaal i saavel det højere som lavere Skolevæsen, samlet Forarbejderne til den Plan for Skolens Ordning, som han havde gjort til sit Livs Opgave at gjennemføre, og nedlagt Frugterne af et rigt pædagogisk Livs Erfaring." Således lød indledningen til en subskriptionsindbydelse til en udgave af Nissens skrifter, som også blev trykt i danske aviser (her gengivet efter Dagbladet (København) 21. sept. 1874.). Nissens praktiske virke begrænsede sig til Norge, men han var ved sin død et kendt navn i hele Skandinavien, dog nok mere i Sverige end i Danmark.

Hartvig Nissen (1815-1874) var præstebarn fra Trøndelag, blev dimitteret fra Trondhjems lærde skole til Det Kgl. Frederiks Universitet i Christiania, hvor han studerede filologi. I 1838 rejste han på et stipendium til København, hvor han antagelig opholdt sig til midt i 1840 . Hjemme i Norge igen måtte han opgive en videnskabelig karriere, og fra han tog filologisk eksamen i 1843, vendte han hele sin opmærksomhed mod pædagogisk virksomhed, først med annoncering af en skole, der skulle forene real- og latinskolens fagsammensætning. Samme år besøgte han Sorø Akademi. I resten af sin karriere forenede han praktisk skolevirksomhed med et pædagogisk forfatterskab og tillidsposter i både foreningslivet og ved Kirkedepartementet. Ved sin død var han en af norsk skolelivs mest indflydelsesrige skikkelser. Nissens liv er velbeskrevet i litteraturen (han er også biograferet i Salmonsens Konversationsleksikon, 2. udg.), og det er den almindelige antagelse, at han modtog væsentlig påvirkning til sit senere virke under sit studieophold i København, mest fra sin lærer J.N. Madvig, der som kultusminister reformerede den lærde skole i 1850. 
Skønt Madvig selv var klassisk filolog, søgte han at styrke de naturvidenskabelige fag på de klassiske sprogs bekostning.

Heroverfor opstiller Merethe Roos den interessante hypotese, at Nissen var påvirket af Grundtvig, og at Christopher Bruun derfor får konkurrence som Grundtvigs væsentligste profet i Norge. Nogen direkte eller personlig kontakt med Grundtvig kan Roos ikke finde. Nissen befandt sig i København, mens Grundtvig holdt sine "Mands Minde"-forelæsninger. Der er ingen dokumentation af, at Nissen var blandt tilhørerne. Roos nøjes med noget besværgende at skrive, at der "er all grunn til å tro at Nissen fulgte disse forelesningene" (15), en antagelse, der gentages et par gange (63, 66 og 67), hvad den ikke bliver mere dokumenteret af. Men det må jo indrømmes, at den har sandsynligheden for sig. Et noget mere håndfast vidnesbyrd om en forbindelse ville man have kunnet opnå ved at studere Det Kongelige Biblioteks udlånsprotokoller for de år, da Nissen var i København. Desværre er protokollerne for både 1838 og 1839 bortkommet, og af de relativt mange udlån af Grundtvig i 1840 er ingen til student Nissen. Til gengæld brevvekslede Nissen med Frederik Barfod, med hvem han stod på venskabelig fod. Er der en forbindelse til det grundtvigske, er den formidlet gennem hans engagement i skandinavismen, som Roos dokumenterer.

Mere substantielt søger Roos at vise ligheden mellem Nissens skoletanker og Grundtvigs. Blandt andre Dag Thorkildsen har været inde på det samme. Metodisk er påstand om påvirkning ved hjælp af påvisning af lighed en lidt vanskeligere øvelse, ikke mindst i Grundtvigs tilfælde, fordi hans pædagogiske ideer ofte er formuleret i noget mere generelle vendinger og dermed også fortolkningsåbne. Det gør det på den ene side vanskeligt at påvise lighed, og på den anden side vanskeligere at afvise, at der skulle have fundet en påvirkning sted. I spørgsmålet om religionens rolle i undervisningen indtog Grundtvig dog et egentligt særstandpunkt, idet han afviste, at troen kunne være en læresag. Om kristendommens status i skolen skrev Nissen således:

Den første Betingelse for, at Skolen skal kunne medvirke kraftig til at styrke sine Lærlinges Religiøsitet er, at den selv er gjennemtrængt af en christelig sædelig Aand. Denne skal ikke fræmtræde i hyppige og moralske religiøse taler; thi derved vil Opdrageren maaske netop modarbejde sin Hensigt; men Skolens hele Virksomhed og dens Læ- 
reres Forhold til Eleverne og til hverandre indbyrdes bør bære den christelige Kjærligheds Præg (100).

I dette ser man en helt klar påvirkning fra Grundtvig, mener Roos. Det er rigtigt, for så vidt Nissen i dette citat læst i sin samtidige kontekst gav udtryk for en nedtoning af den direkte forkyndelse. Men spørgsmålet er, om dette ikke også kan tages som udtryk for den almindelige opfattelse i tiden - uden for vækkelserne - at sand kristendom først og fremmest ytrede sig i det sædelige liv. Skal man endelig pege på en mulig dansk påvirkning i den retning, skulle det være Martensen snarere end Grundtvig. Men der er nok snarere tale om en gængs borgerlig kristendom anno dazumal.

Et større sammenfald med Grundtvigs ideer finder man i Nissens tanker om sprog og folkeånd ( 83 f.) og dermed modersmålets betydning for undervisningen. Her står Roos på fastere grund. Hun peger også på påvirkningen fra Madvig, idet Nissen også lagde vægt på fremmedsprogenes betydning og den rækkefølge, i hvilken de introduceredes for disciplene.

Skal man pege på en sammenhæng mellem Nissen og Grundtvig, som Roos ikke gør meget ud af, er det ikke ligheden i tanken, men i erfaringen. Som Nissen begyndte Grundtvig som filolog med videnskabelige ambitioner, men måtte på et tidligt tidspunkt søge sit udkomme som lærer for børn og unge, og han var, som Holger Berg understreger det i sin indledning til Historisk Børnelardom (1829) på grundtvigsværker.dk, en noget mere rutineret praktiker, end man normalt giver ham æren for. Han underviste som ung på det dengang moderne Schouboeske Institut og var gode venner med realskolebestyrer Mariboe (se Else Riisagers indledning til Morgensange (1833) på grundtvigsværker.dk). Nissen refererede i øvrigt direkte til Mariboe i en diskussion om pigers skolegang (97 f.). Endelig må det ikke glemmes, hvad Roos da heller ikke gør, og retfærdigvis indrømmes, at Grundtvig fra 1841 var direktør for Dronning Caroline Amalies Asylskole i Kronprinsessegade, om end Roos placerer den i Nørregade (51). Det er imidlertid bemærkelsesværdigt, at der er så relativt svag en sammenhæng mellem Grundtvigs erfaringer og kundskaber på den ene side og hans skoletanker på den anden.

Han var en fremragende latiner og beherskede moderne engelsk nok til at fungere som tolk, da Elizabeth Fry besøgte Danmark. At han kunne tysk, var en selvfølge. Men alligevel spiller hverken de klassiske eller moderne hovedsprog nogen rolle i hans programmatiske skoleskrifter. På den 
ene side er det interessant, at han ikke gjorde sig selv til målestok for sine idealer, men på den anden er der tale om en påfaldende ufølsomhed over for egne erfaringer. Grundtvig burde om nogen vide, hvor nyttigt det var at beherske fremmedsprog. I denne sag havde Nissen et lidt kraftigere remtræk til virkeligheden og derfor også en noget større indflydelse på det offentlige skolevæsen.

Roos præsenterer sine resultater redeligt og åbent. Denne anmelder er som antydet ikke overbevist af hovedtesen. Det gør ikke undersøgelsen mindre interessant, fordi den også lægger sine præmisser åbent frem og kvalificerer den fortsatte diskussion af Grundtvigs betydning. Og så trækker det jo bestemt ikke ned, at vi hermed får en opdateret introduktion til en af norsk skolevæsens væsentligste skikkelser. 